Article

\title{
Plasmid curing pattern of nosocomial pathogens of intensive care units (ICU) in Zagazig University Hospital
}

Soheir El-Salam ${ }^{1 *}$, Mohammed Farouk Ghaly ${ }^{2}$, Ahmed Anwar Shahen ${ }^{3}$, Mahmoud Mostafa Amer ${ }^{4}$ and Sanaa Atef Abdelkader ${ }^{5}$

${ }^{1}$ Botany Department, Faculty of Science, Benha University, Egypt

${ }^{2}$ Botany Department, Faculty of Science, Zagazig University, Egypt

${ }^{3}$ Microbiology Department, Faculty of Medicine, Zagazig University, Egypt

${ }^{4}$ Botany Department, Faculty of Science, Benha University, Egypt

${ }^{5}$ Faculty of Science, Benha University, Egypt

${ }^{*}$ Corresponding author: Dr. Soheir El-Salam, Botany Department, Faculty of Science, Benha University, Egypt. E-mail: Dr.soheir_saad@yahoo.com

Received: 09 October 2016/Accepted: 16 November 2016/ Published: 29 December 2016

\begin{abstract}
Nosocomial infections and antibiotic resistance are serious and growing phenomenon in contemporary medicine and has emerged as one of the public health concerns. A total of seventy isolates of bacteria were collected from patients. The selected isolates include $33(56.9 \%)$ from males and 25 (43.1\%) from females. All bacteria were susceptible to imipenem followed by amikacin, ceftazidime, ciprofloxacin and tobramycin, respectively. The multi-drug resistant (MDR) bacterial isolates (33 isolates) divided into four groups named Escherichia coli, Klebsiella pneumoniae, Pseudomonas aeruginosa, and Staphylococcus aureus were selected to be identified according to the keys of different identification protocols. Escherichia coli found to be the most frequent pathogen within MDR isolates followed by Staphylococcus aureus, Pseudomonas aeruginosa and Klebsiella pneumonia, respectively. The MICs and MBCs of (Imipenem, Amikacin, Ceftazidime and ciprofloxacin) against the most resistant isolates were determined. Generally, $P$. aeruginosa (Strain No. 55) was found to be the highest resistant bacteria. Plasmid profile of Pseudomonas aeruginosa was carried out, after incubation at $37^{\circ} \mathrm{c}$ for $24 \mathrm{hr}$ recorded no changes in plasmid and compared with incubation at $43^{\circ} \mathrm{c}$ (plasmid curing) which showed complete removal of plasmid bands and the tested bacteria became more sensitive to antibiotics. This study therefore determined the prevalence, anti-biotic susceptibility and plasmid patterns of $P$. aeruginosa strains from clinical specimens obtained from the intensive care units of Zagazig University Hospital in Egypt.
\end{abstract}

Keywords: plasmid curing; nosocomial infection; antibiotic susceptibility; minimum inhibitory concentration; minimum bactericidal concentration

\footnotetext{
1. Introduction

Nosocomial infections are a leading cause of morbidity and mortality among hospitalized patients. These infections involve $5 \%$ to $15 \%$ of hospitalized patients and can lead to complications in $25 \%$ to $50 \%$ of those admitted to intensive care units ICUs) (Filetoth, 2008).

Pathogenic organisms that cause nosocomial infections can be transmitted to the community in a number of different ways and particularly through health staff, visitors and discharged patients. The characteristics of the micro-organisms including their level of antibiotic resistance, innate virulence, amount inoculums of microbial agent and patient susceptibility were studied by (Roach et al., 2015).
} 
Antibiotic resistance is a global problem, but poor and developing nations are more affected due to the fact that antibiotics can be obtained easily over the counter without doctors' prescriptions, whereas in the developed countries access to antibiotics is much more limited (Alanis, 2005; Hagi Saghati et al., 2015).

The main factors that lead to microbial resistance and the spread of multi-drug resistance organisms are thought to be the misuse of antibiotics by healthcare workers. The term multi-drug resistance (MDR) is used to describe bacteria that are able to resist one or more antibiotics in three or more antibiotic classes, while bacterial strains that are resistant to all antibiotics are termed as extreme drug resistant strains (Bassetti et al., 2013).

Multidrug resistant Enterobacteriaceae have become an important cause of urinary tract and blood stream infections within the community setting (Steindl et al., 2012). Pseudomonas aeruginosa is a major nosocomial pathogen worldwide, intrinsically resistant to many drugs. There are many challenges in the treatment of (MDR) $P$. aeruginosa, especially considering the absence of new antimicrobials in the drug-development pipeline (Zavascki et al., 2010).

Plasmid is extra chromosomal DNA present in the cytoplasm of the cell, double stranded, circular DNA, self reproducing, many plasmids are transferred among bacterial cells such plasmids can lead to dissemination throughout a population, frequently containing genes that convey antibiotic resistance or toxin production (Saffar et al., 2008). The transfer of resistance genes by plasmids is more effective than chromosomal mutation (Alekshun \& Levy, 2007).

The present work was aim to Studying the susceptibility and resistance of isolated bacteria to different antibiotics and determination of MICs and MBCs of some antibiotics against multi-resistant isolates and studying the analysis of plasmid profile for multi-drug resistant isolates.

\section{Materials and Methods}

\subsection{Samples collection}

Seventy isolates of bacteria were collected from Zagazig University hospital's intensive care units (ICUs). The samples were collected from Patients, tools, air, floor, wall and nursery incubators. The patient data (Age, Gender, Type of infection and drugs) were collected. The specimens were collected and transported according to Murray et al. (2007) under aseptic conditions quickly to the Microbiology Laboratory at Faculty of Science, Zagazig University where the study was carried out.

\section{2. Isolation, identification and characterization of bacterial isolates}

Bacterial isolates were isolated and streaked for several consecutive times on nutrient agar medium until pure single colonies were obtained. Preliminary identification of bacteria was based on colonial morphology of the organisms such as hemolysis on blood agar, changes in physical appearance in differential media and enzyme activities of the organisms. Biochemical tests were performed on colonies from primary cultures for identification and characterization of the isolates.

The purified cultures of the selected multi-drug resistant isolates were identified and confirmed after investigating morphological cultural characters and biochemical tests according to standard clinical laboratory methods reported and recommended by Bergey's Manual of determinative bacteriology (Garrity et al., 2005; Vos et al., 2009) and others (Gillespie \& Hawkey, 2006; Mahon et al., 2011).

\subsection{Antibiotic susceptibility tests}

Ten of different antibiotics were selected for carrying out the antimicrobial susceptibility test. The antibiotic discs used in this research were purchased from Oxoid Ltd., England. The name of antibiotic discs, the code, the potency and the standard evaluation of inhibition zones were tested according to D'Amato et al. (1985) and CLSI (2008).

Antibiotic susceptibility test for the bacterial isolates was carried out by Kirby Bauer disc diffusion technique according to Bauer et al. (1966). Mueller-Hinton agar was used for testing the sensitivity of the experimental isolates to the different antibiotics (Mueller and Hinton, 1941). The appropriate antibiotics were placed in the agar aseptically using sterile forceps the plates were then incubated at $37^{\circ} \mathrm{C}$ for 24 hours. The antibiotics discs

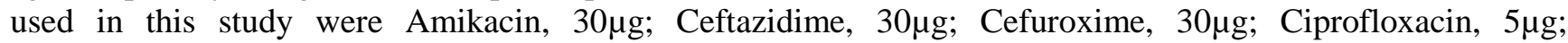

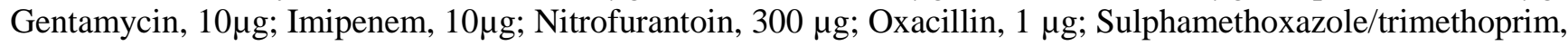
$25 \mu \mathrm{g}$; Tobramycin, $10 \mu \mathrm{g}$. 
2.4. Determination of the minimum inhibitory concentrations (MICs) and minimum bactericidal concentrations (MBCs) of selected antibiotics against selected isolates

Four antibiotics (the most effective antibiotics) were used; Imipenem (a member of Carbapenems family), Amikacin (a member of Aminoglycosides family), Ceftazidime (a member of Cephalosporins family) and Oxacillin (a member of Penicillins family) against the most resistant isolates: E. coli (59), K. pneumoniae (42), $P$. aeruginosa (55) and $S$. aureus (17).

The MICs and MBCs were determined by using the standard broth dilution technique according to Washington, 1985 and Marie, 2005. The stock solution of the antibiotics was diluted with sterile nutrient broth (double strength) to obtain an appropriate dilution needed for each experiment (as micrograms per milliliter).

In Wassermann tubes two fold serial dilutions of one of the antibiotics were made from the diluted stock solution using broth as diluents. To each tube $0.5 \mathrm{ml}$ nutrient broth containing tested organism $(24 \mathrm{~h}$. ages) was added. A control tube for each group of tests was un-inoculated medium with and without antibiotic was included to ensure sterility and clarity of the medium. A third control tube containing inoculated medium but without antibiotic was also included to ensure the ability of the organism to grow in the medium. All the tubes were incubated at $37^{\circ} \mathrm{C}$ for $24 \mathrm{~h}$. and examined for turbidity as an indicator of bacterial growth.

The minimum inhibitory concentration (MIC) is defined as the lowest concentration that inhibits a visible growth in liquid media. One hundred micro liters $(\mu \mathrm{l})$ were taken from each MIC concentration as well as less and more than MIC concentrations and introduced onto nutrient agar to determine the MBC. The plates were incubated at $37^{\circ} \mathrm{C}$ for $24 \mathrm{~h}$. The minimum bactericidal concentration (MBC) is the lowest concentration at which no growth occurs on solid media.

\subsection{Plasmid curing}

Plasmids can be eliminated (cured) from bacteria by several chemical and physical agents.

\subsection{Plasmid isolation and sample preparation}

Plasmid DNA was extracted using Bacterial Total DNA Isolation by Alkaline Method Kit (Khalil et al., 2011). In an eppendorf, $1.5 \mathrm{ml}$ from overnight culture were taken, centrifuged at 8,000 x g for $1 \mathrm{~min}$, pellet was kept and $25 \mu \mathrm{l}$ of solution A was added, mixed by automatic pipette up and dawn. Then $250 \mu \mathrm{l}$ of solution B was added and mixed by moving up and down three times. Then $250 \mu \mathrm{l}$ of solution $\mathrm{C}$ was added and centrifuged at $13,000 \mathrm{x} g$ for $5 \mathrm{~min}$. Finally, the upper phase was removed into new eppendorf. After extraction of the DNA samples, an appropriate amount was transferred (about $25 \mu \mathrm{l}$ ) of each sample to a fresh eppendorf and $5 \mu \mathrm{l}$ of loading buffer was added.

\subsection{Samples loading and running}

The first well was loaded with DNA marker. Samples were loaded from right to left, and the gel chamber was closed. The power-source switched on $5 \mathrm{~V} / \mathrm{cm}$. The run was monitored by reference to the marker dye. Finally, the run was stopped when the bromophenol blue had reached 3/4 the length of the gel.

\subsection{Staining and examination:}

After removing the gel from the chamber, the gel was placed in the ethidium bromide solution inside dark container, leaved for about $30 \mathrm{~min}$ then washed by placing the gel in another container having 1xTAE buffer for about $20 \mathrm{~min}$, the gel was examined by UV Trans-illuminator and photographed.

\subsection{Plasmid curing by elevated temperature}

Bacterial growth in with $10^{4} \mathrm{cell} / \mathrm{ml}$ nutrient broth was grown to late phase at an elevated temperature $43{ }^{\circ} \mathrm{C}(5-7$ ${ }^{\circ} \mathrm{C}$ above the normal growth temperature, the culture was diluted $1: 20$ by taking $0.5 \mathrm{ml}$ of the bacterial growth into $10 \mathrm{ml}$ of nutrient broth and the culture was grown at $43{ }^{\circ} \mathrm{C}$ for 24 hour. Two drops of the treated culture were placed on nutrient agar plates to obtain separate colonies, individual colonies were tested for loss plasmidcoded functions (streptomycin and tetracyline resistance) (Sambrook et al., 1989).

\subsection{Antibiotic sensitivity after plasmid curing}

Antibiotic sensitivity tests of the isolated strains after plasmid curing were done by the disc diffusion method with the same antibiotics and the same concentrations as before plasmid curing. The sensitivity of the bacterial organisms to different antibiotics discs were measured according to Lenette et al. (1974). 


\section{Results and Discussion}

Nosocomial infections are frequent complications of hospitalizations. In this study seventy isolates of bacteria were collected from patients at Zagazig University hospital's intensive care units (ICUs). The selected isolates include $33(56.9 \%)$ isolates from males and $25(43.1 \%)$ isolates from females whose ages ranged between 25 to 85 years. (Izquierdo et al., 2008), were reported a significant relationship between age and nosocomial infections.

\subsection{Antibiotic susceptibility tests}

The susceptibility of the different bacterial isolates which isolated from the tested clinical specimens towards ten of different antibiotics by using a standardized disc diffusion method was carried out. The results in Table 1 and Figure 1 revealed that the tested isolates were highly susceptible to imipenem with susceptibility percentage $(54.3 \%)$ so that it represented the most effective antibiotic followed by amikacin, ceftazidime, ciprofloxacin and tobramycin with $48.6 \%, 44.3 \%, 44.3 \%$ and $42.9 \%$ susceptibility, respectively. On the other hand the data showed that $61.4 \%$ of bacterial isolates were resistant to nitrofurantoin while $55.7 \%$ and $52.9 \%$ of bacterial isolates were resistant to sulphamethoxazole/trimethoprim and cefuroxime, respectively. These results are in agreement with Reddy et al. (2016) they reported that maximum sensitivity was seen for imipenem (82\%), followed by piperacillin + tazobactam $(76 \%)$, amikacin $(71 \%)$, ciprofloxacin $(63 \%)$, gentamycin $(58 \%)$, and ofloxacin (63\%). High resistance was identified with co-trimoxazole (54\%), ceftriaxone (66\%), and doxycycline (85\%). Das et al. (2006) showed that the susceptibility rate of clinical isolates was the highest for amikacin (87.2\%), followed by ciprofloxacin $(74.8 \%)$, ceftazidime $(71.5 \%)$ and gentamicin $(70.4 \%)$. Generally, the tested isolates showed high resistance to $\beta$-lactam antibiotics. This is agree with Giacommetti et al. (2000) who found that all 94 strains of $P$. aeruginos $a$ and $E$. coli tested isolates were resistant to at least $7 \beta$-lactam antibiotics.

\subsection{Frequency of different bacterial groups within multi-drug resistant bacterial isolates}

In our study (Table 2), the multi-drug resistant (MDR) bacterial isolates (33) isolates were distributed as 23 gram negative bacterial isolates (69.7\%) and 10 gram positive bacterial isolates (30.3\%). And divided into four groups namely, Escherichia coli, Klebsiella pneumoniae, Pseudomonas aeruginosa, and Staphylococcus aureus. Escherichia coli was the most frequent pathogen within MDR isolates representing 36.4\% of MDR isolates followed by Staphylococcus aureus and Pseudomonas aeruginosa with frequency percentage 30.3\% and $21.2 \%$, respectively. On the other hand Klebsiella pneumoniae was the less frequent pathogen within MDR isolates (12.1\%). Rangel et al. (1999) found that the microorganisms most commonly isolated from clinical specimens were E. coli (28\%), S. aureus (11.11\%) and P. aeruginosa (8.6\%). Yuksel et al. (2006) reported that the most causative agents was E. coli (87\% of cases) followed by K. pneumonia (10\%). But in other study nosocomial infections were most frequently caused by Acinetobacter (34.5\%), followed by Pseudomonas (32.8\%), Klebsiella (13.9\%), E. coli (12.1\%) and Citrobacter (5\%) (Pradhan et al., 2014).

Escherichia coli infection is one of the major public health problems in many developing countries and has contributed exceedingly to morbidity, mortality and increased health costs (Ogata et al., 2002). K.

pneumoniae pneumonia causes a severe, rapid-onset illness that often causes areas of destruction in the lung, and causes less serious respiratory infections, such as bronchitis, which is usually a hospital-acquired infection (Brochert, 1999). Staphylococcus aureus is well documented as a human opportunistic pathogen and one of the most frequently identified pathogens in clinical laboratories (Merlino et al., 1996). S. aureus is notorious for its ability to develop broad antibiotic resistance. The most commonly known resistance of S. aureus is (MRSA), the new strain resistant to vancomycin, (VRSA), this organism poses a major threat to human health globally (Lee et al., 2015).

Pseudomonas aeruginosa is identified as one of the most common pathogen causing hospital acquired infections (Geffers et al., 2004).

\subsection{The minimum inhibitory concentrations (MICs) and minimum bactericidal concentrations (MBCs) of most effective antibiotics against the most resistant strains}

Four antibiotics (the most effective antibiotics) were used; imipenem (a member of carbapenems family), amikacin (a member of aminoglycosides family), ceftazidime (a member of cephalosporins family) and ciprofloxacin (a member of fluoroquinolones family) against the most resistant isolates: $E$. coli (59), $K$. pneumoniae (42), P. aeruginosa (55) and S. aureus (17).

Values of MICs and MBCs were determined by using the standard broth dilution technique and were shown in Table (3), The highest MIC and MBC were observed in ciprofloxacin antibiotic against $P$. aeruginosa (55) 


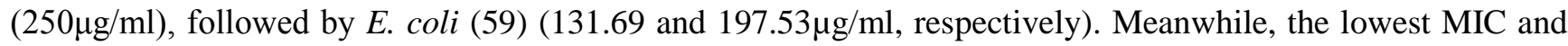
MBC were observed in imipenem and amikacin antibiotics for $S$. aureus (17).

Gram negative bacteria were more resistant than gram positive ones, so we used higher concentrations of antibiotics for inhibiting the growth (MIC) or killing (MBC) gram negative bacteria more than that used with gram positive. Most studies show that the high prevalence of gram-negative bacteria isolated from patients in ICUs is associated with a high rate of mortality (Ak et al., 2011). Our study documented an antibiotic resistance develops when microorganisms are exposed to effective doses of an antibiotic within a shorter period or when the microorganisms are exposed to smaller concentrations or residues of the antibiotic over a longer period of time (Todar, 2008).

Table 1. Comparative susceptibility of bacterial isolates against different antibiotics.

\begin{tabular}{|c|c|c|c|c|c|c|c|c|}
\hline \multirow{2}{*}{ Antibiotic } & \multirow{2}{*}{ Symbol } & \multirow{2}{*}{$\begin{array}{l}\text { Conc. } \\
\mu \mathrm{g} / \text { disc }\end{array}$} & \multicolumn{2}{|c|}{ Resistant (R) } & \multicolumn{2}{|c|}{ Intermediate (I) } & \multicolumn{2}{|c|}{ Susceptible (S) } \\
\hline & & & No. & $\%$ & No. & $\%$ & No. & $\%$ \\
\hline Imipenem & IPM & 10 & 27 & 38.5 & 5 & 7.1 & 38 & 54.3 \\
\hline Amikacin & $\mathrm{AK}$ & 30 & 28 & 40 & 8 & 11.4 & 34 & 48.6 \\
\hline Ceftazidime & CAZ & 30 & 35 & 50 & 4 & 5.7 & 31 & 44.3 \\
\hline Ciprofloxacin & CIP & 5 & 36 & 51.4 & 3 & 4.3 & 31 & 44.3 \\
\hline Tobramycin & TOB & 10 & 36 & 51.4 & 4 & 5.7 & 30 & 42.9 \\
\hline Oxacillin & OX & 1 & 30 & 42.9 & 11 & 15.7 & 29 & 41.4 \\
\hline Gentamycin & $\mathrm{CN}$ & 10 & 37 & 52.9 & 4 & 5.7 & 29 & 41.4 \\
\hline Cefuroxime & CXM & 30 & 34 & 48.6 & 9 & 12.9 & 27 & 38.5 \\
\hline $\begin{array}{l}\text { Sulphamethoxazole/trimet } \\
\text { hoprim }\end{array}$ & SXT & 25 & 39 & 55.7 & 6 & 8.6 & 25 & 35.7 \\
\hline Nitrofurantoin & $\mathrm{F}$ & 300 & 43 & 61.4 & 6 & 8.6 & 21 & 30 \\
\hline
\end{tabular}

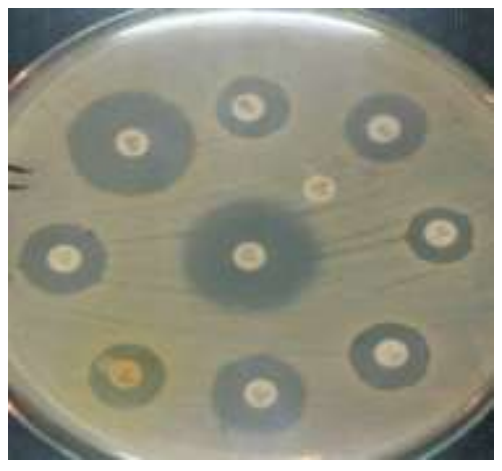

(a)

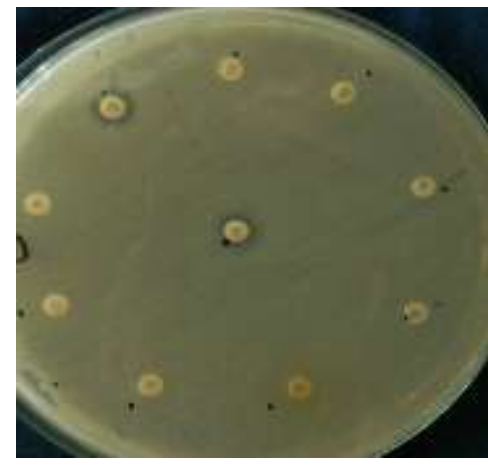

(b)

Figure 1. Antibiotic susceptibility test (a), sensitive isolate and (b), resistant isolate.

Table 2. Frequency of different bacterial groups within multi-drug resistant bacterial isolates.

\begin{tabular}{lllll}
\hline Group no. & Bacterial species & Isolates no. & Total no. & Percentage (\%) \\
\hline I & Escherichia coli & $2,8,9,11,15,20,23,29,35,38,48$ and 59 & 12 & 36.4 \\
II & Staphylococcus aureus & $1,10,16,17,25,37,40,53,65$ and 68 & 10 & 30.3 \\
III & Pseudomonas aeruginosa & $18,21,27,28,49,55$ and 63 & 7 & 21.2 \\
IV & Klebsiella pneumoniae & $22,24,42$ and 70 & 4 & 12.1 \\
Total & & & 33 & 100 \\
\hline
\end{tabular}

Table 3. The (MICs) and (MBCs) of most effective antibiotics against the most resistant strains.

\begin{tabular}{|c|c|c|c|c|c|c|c|c|}
\hline \multirow[t]{2}{*}{ Bacterial isolate } & \multicolumn{2}{|c|}{$\begin{array}{c}\text { Imipenem } \\
\text { (IPM) }\end{array}$} & \multicolumn{2}{|c|}{$\begin{array}{c}\text { Amikacin } \\
\text { (AK) }\end{array}$} & \multicolumn{2}{|c|}{ Ceftazidime (CAZ) } & \multicolumn{2}{|c|}{ Ciprofloxacin (CIP) } \\
\hline & $\begin{array}{l}\mathrm{MIC}(\mu \mathrm{g} / \\
\mathrm{ml})\end{array}$ & $\begin{array}{l}\operatorname{MBC}(\mu \mathrm{g} \\
/ \mathrm{ml})\end{array}$ & $\begin{array}{l}\mathrm{MIC}(\mu \mathrm{g} / \\
\mathrm{ml})\end{array}$ & $\begin{array}{l}\mathrm{MBC}(\mu \mathrm{g} / \\
\mathrm{ml})\end{array}$ & $\begin{array}{l}\mathrm{MIC}(\mu \mathrm{g} / \\
\mathrm{ml})\end{array}$ & $\begin{array}{l}\operatorname{MBC}(\mu \mathrm{g} \\
/ \mathrm{ml})\end{array}$ & $\begin{array}{l}\mathrm{MIC}(\mu \mathrm{g} / \\
\mathrm{ml})\end{array}$ & $\begin{array}{l}\mathrm{MBC}(\mu \mathrm{g} \\
/ \mathrm{ml})\end{array}$ \\
\hline E. coli (59) & 62.5 & 125 & 87.791 & 131.687 & 125 & 197.53 & 131.69 & 197.53 \\
\hline K. pneumoniae (42) & 39.018 & 39.018 & 62.5 & 87.791 & 62.5 & 125 & 87.791 & 125 \\
\hline P. aer & 58.527 & & 125 & 125 & 125 & 25 & 250 & 250 \\
\hline S. aureus (17) & 7.813 & 15.625 & 15.625 & 26.012 & 26.012 & 31.25 & 39.018 & 58.527 \\
\hline
\end{tabular}




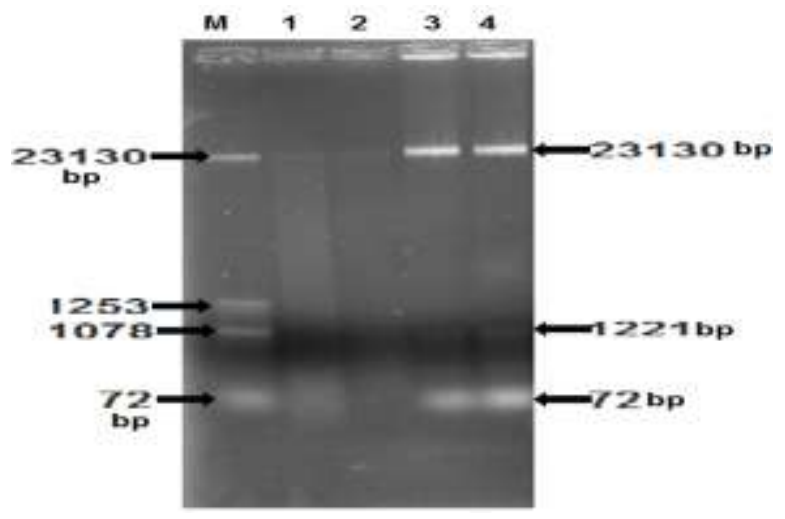

Figure 2. Plasmid profile of the most resistant clinical isolate.

Lane $1 \& 2$ : treated bacteria at $43^{\circ} \mathrm{c}$ Lane $3 \& 4$ : treated bacteria at $37^{\circ} \mathrm{c}$

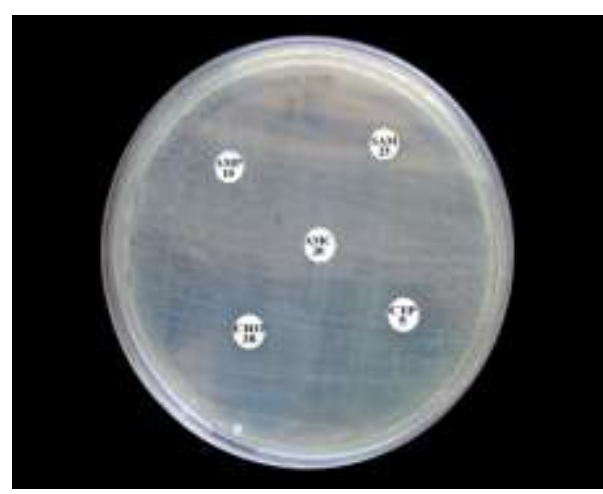

Figure 3(A). Antibiotic sensitivity test for Pseudomonas aeruginosa before plasmid curing.

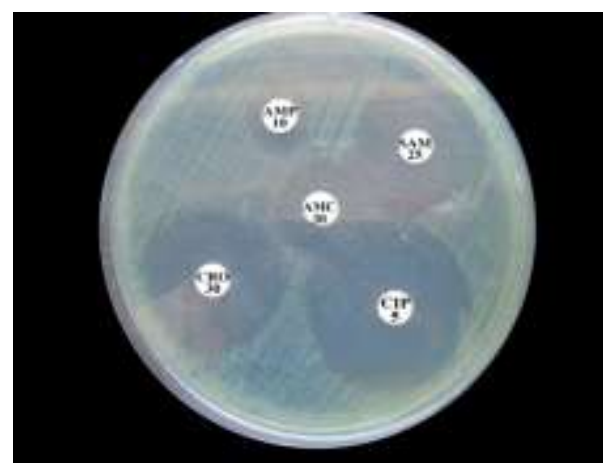

Figure 3(B). Antibiotic sensitivity test for Pseudomonas aeruginosa after plasmid curing.

\subsection{Plasmid curing}

3.5.1. Isolation of plasmid DNA profile of most clinical bacteria multiresistant to antibiotics

Plasmid is extra chromosomal DNA present in the cytoplasm of the cell, double stranded, circular DNA, self reproducing, many plasmids are transferred among bacterial cells such plasmids can lead to dissemination throughout a population, frequently containing genes that convey antibiotic resistance or toxin production (Saffar et al., 2008).

In our study the plasmid profile of the most multi resistant clinical isolate, Pseudomonas aeruginosa (55) were carried out to detect plasmid bands and its molecular weight. Plasmid DNA isolation from our isolate showed that after incubation at $37^{\circ} \mathrm{c}$ for $24 \mathrm{hr}$ harboring a plasmid which recorded no change in plasmid. The DNA profile at lane $3 \& 4$ showed three bands at $23.130 \mathrm{bp}, 1221 \mathrm{bp}$ and $72 \mathrm{bp}$ compared with tested bacteria incubated at $43^{\circ} \mathrm{c}$ which showed complete removal of plasmid bands and the tested bacteria become more sensitive to antibiotics. 
The obtained results in Figure 2 clearly indicated complete curing of plasmid at lane 1 and lane 2, compared with the same tested bacteria incubated at $37^{\circ} \mathrm{C}$.

Some of the resistant determinant are part of the transposable DNA sequences that can even the whole plasmids could also be stably integrated into the undergo translocation to multiple chromosomal and plasmid sites and chromosome (Fluit et al., 2001).

On the other hand, plasmid DNA profile can be used as an epidemiological marker, but in combination with other typing methods and with antibiotic resistance patterns to characterize the circulation of $P$. aeruginosa strains and the spread of resistance in these bacteria (Millesimo et al., 1996).

Plasmids can be spontaneously lost from or readily acquired by a host strain as they are mobile, extra chromosomal elements and not part of the chromosomal genotype that defines the host strain. In addition, there were correlation existed between the antibiotic susceptibility pattern of the most resistant strains and their plasmid profiles (Marian, 2004).

Some antibiotic resistance genes were found on non conjugative plasmids, these genes may also move from one plasmid to another (Walker, 1998). The unstable nature of plasmids that can spread even to multiple species of bacteria and may be lost or acquired spontaneously (Morlin et al., 1994), make plasmid fingerprinting, which was the first molecular typing method to be used for epidemiological purposes often poorly reproducible (Stefani and Agodi, 2000).

The emergence and spread of plasmid-mediated $\beta$-lactamases such as extended-spectrum $\beta$-lactamases (ESBLs), and other inhibitor-resistant derivatives have been potentiated by the use and over-use of broad-spectrum $\beta$ lactam antibiotics. The genes encoding these $\beta$-lactamases are 3 often located on large plasmids that also encode genes for resistance to other antibiotics, including aminoglycosides, tetracycline, sulfonamides, trimethoprim and chloramphenicol) (Hanson et al., 1999).

\subsubsection{Antibiotic sensitivity after plasmid curing}

The sensitivity test for imipenem, amikacin, ciprofloxacin, tobramycin, ceftazidime, were tested against clinical Pseudomonas aeruginosa before and after plasmid curing and the obtained results illustrated in Figures 3(A) \& 3(B). These results clearly demonstrated that the sensitivity of tested Pseudomonas aeruginosa increasing at degree of inhibition zone formed if compared with non cured plasmid and the highest inhibition zone were obtained with ciprofloxacin followed by ceftriaxone. After plasmid curing and the diameter of inhibition zone differs according to antibiotics tested.

\section{Conclusions}

Since it is evident and established that some of the isolates from hospitals in Egypt, could pose a serious health hazard. Their occurrence and prevalence could be attributed to poor hand hygiene, cross contamination between the patients and hospital personnel, misuse of drug can lead to multidrug resistance which can lead to limited choice of antimicrobial agents and transfer of such MDR to un-pathogenic enteric organisms. Application of strict prevention strategies including changes in antibiotic treatment regimens, hygiene measures, infection prevention and control of horizontal nosocomial transmission of organisms is desirable. On the whole, principle of antimicrobial stewardship is urgently needed to preserve efficacy of available antimicrobial agents.

\section{Conflict of interest}

None to declare.

\section{Reference}

Abdel Rahman S, S Abd-Ellatif, S Deraz and A Khalil, 2011. Antibacterial activity of some wild medicinal plants collected from western Mediterranean coast, Egypt: Natural alternatives for infectious disease treatment. Afr. J. Biotechnol., 10 10733-10743.

Ak O, A Batirel, S Ozer and S Colakoglu, 2011 Nosocomial infections and risk factors in the intensive care unit of a teaching and research hospital: A prospective cohort study. Med. Sci. Monit., 17: 29-34.

Alanis AJ, 2005. Resistance to Antibiotics: Are we in the Post-Antibiotic Era? Arch. Med. Res., 36: 697-705.

Alekshun MN and SB Levy, 2007. Molecular mechanisms of antibacterial multidrug resistance. Cell, 128:10371050.

Bassetti M, M Merelli, C Temperoni and A Astilean, 2013. New Antibiotics for Bad Bugs: Where are we? Ann. Clin. Micro. Antimic., 12, 1186-1198.

Bauer AW, WMM Kirby, JC Sherries and M Truck, 1966. Antibiotic susceptibility testing by a standardized single disk method. Am. J. Clin. Pathol., 45: 493-496. 
Brochert MD 1999. Klebsiella: One potentially nasty bacteria. http://www.personalmd.com/news/ klebsiella_102299.shtml

CLSI (Clinical and Laboratory Standards Institute), 2008. Performance standards for Antimicrobial susceptibility testing; $18^{\text {th }}$ informational supplement. M100-S18, Wayne, PA.

D'Amato RF and L Hochstein, 1985. Evaluation of a rapid inoculum preparation method for agar disk diffusion susceptibility testing. J. Clin. Microbiol., 15:282-285.

Das RN, TS Chandrashekhar, HS Joshi, M Gurung, N Shrestha and PG Shivananda, 2006. Frequency and susceptibility profile of pathogens causing urinary tract infections at a tertiary care hospital in western Nepal. Singapore. Med. J., 47: 281-285.

Filetoth Z, 2008. Infection Control and Surveillance, in Hospital-Acquired Infection: Causes and Control, Whurr Publishers Ltd, Philadephia, Pa, USA.

Fluit ADC, MR Visser and SJ Scmitz, 2001. Molecular detection of antimicrobial resistance. Clin. Microbial. Rev., 14:836-871.

Garrity GM, DJ Brenner, NR Krieg and JT Staley, 2005. Bergey's Manual of Systematic Bacteriology. 2nd ed. Vol. 2: The Proteobacteria. Part B: The Gammaproteobacteria. Springer, New York.

Geffers C, I Zuschneid, D Sohr, H Ruden and P Gastmeier, 2004. Microbiological isolates associated with nosocomial infections in intensive care units: Data of 274 intensive care units participating in the German Nosocomial Infections Surveillance System KISS. Anasthesiol Intensivmed Notfallmed Schmerzther; 39: 15-19.

Giacommetti A, O Ciriani, AM Schimizzi, MS Delprete, F Barchiesi, MM Derrico, E Petrelli and G Scalise, 2000. Epidemiology and microbiology of surgical wound infections. J. Clin. Microbiol., 38: 918-922.

Gillespie SH and PM Hawkey, 2006. Principles and Practice of Clinical Bacteriology. 2nd ed. John Wiley \& Sons, Ltd, UK.

Hagi Saghati Sh, H Mobaiyen and Z Bayatmakoo, 2015. Antibiotic Susceptibility of Aerobic Gram-Negative Bacilli Isolated From Patients Admitted in Intensive Care Units of Sina Hospital, Tabriz, Iran. Cres. J. Med. Biol. Sc., 2: 71-75.

Hanson ND, KS Thomson, ES Moland, CC Sanders, G Berthold and RG Penn, 1999. Molecular characterization of a multiresistant Klebsiella pneumoniae encoding ESBLs. J. Antimicro. Chemo., 4: 377380.

Izquierdo CF, A Zambrano and I Frometa, 2008. National prevalence of nosocomial infections. Cuba. J. Hospital Infect.; 68: 234-240.

Lee Y, J Chen, H Lin, H Liu, Sh Lin, H Lin, Ch Fang and P Hsueh, 2015. Impact of active screening for methicillin-resistant Staphylococcus aureus (MRSA) and decolonization on MRSA infections, mortality and medical cost a quasi-experimental study in surgical intensive care unit. Critical Care, 19:143-153.

Lennette EH, EH Spaulding and JP Truant, 1974. Dilution test procedures. Manual of Clinical Microbiology. American Society for Microbiology, Washington, DC, pp. $410-417$.

Mahon CR, DC Lehman and G Manuselis, 2011. Textbook of diagnostic microbiology, 4th ed. W. B Saunders Co., Philadelphia, PA.

Marian AG 2004. Antibiotic susceptibility pattern of Gram-positive Cocci isolates from different clinical samples in Sharkia governorate with DNA study of the most resistant strains. M. Sc thesis Dep. Of microbiology and Immunology. Faculty of Medicine, Zagazig Univ., Egypt.

Marie BC 2005. Manual of antimicrobial susceptibility testing, ASM press, Washington, D.C.

Merlino J, R Goll and GJ Robertson, 1996. Application of Lipovitellin salt Mannitol agar for screening, isolation and presumptive identification of Staph aureus in teaching hospital , J. Clin. Microbiol., 34: 3012 3015.

Millesimo M, GD Intinis, MG Chirillo, T Mussot and D Savoia, 1996. Pseudomonas aeruginosa clinical isolates : serotypes , resistance phenotypes and plasmid profile. Eur. J. Epidemiol., 12: 123-129.

Morlin GL, DL Hedges, AL Smith and JL Urns, 1994. Accuracy and cost of antibiotic susceptibility testing of mixed morphotypes of P. aeruginosa. J. Clin. Microbiol. 32: 1027-1030.

Mueller JH and J Hinton, 1941. A protein-free medium for primary isolation of gonococcus and meningococcus. Proc. Soc. Exp. Biol. Med., 48: 330-333.

Murray PR, EJ Baron, JH Jorgensen, ML Landry and MA Pfaller, 2007. Manual of Clinical Microbiology, 9th Ed., ASM Press, Washington, D.C.

Ogata K, R Kato, K Ito and S Yamada, 2002. Prevalence of Escherichia coli possessing the eaeA gene of enteropathogenic E. coli (EPEC) or the aggR gene of enteroaggregative E. coli (EAggEC) in traveler's 
diarrhoea diagnosed in those returning to Tama, Tokyo from other Asian countries. Jpn. J. Infect. Dis., 55:14-18.

Pradhan NP, SM Bhat and DP Ghadage, 2014. Nosocomial Infections in the Medical ICU : A Retrospective Study Highlighting their Prevalence, Microbiological Profile and Impact on ICU Stay and Mortality. J. Assoc. Phys. Ind., 62: 18-21.

Rangel FMS, GD Morales, MR Baez, BJ Ibarra and RS Leon, 1999. Evaluation of a nosocomial infection surveillance program. Salud Publica Mex., 41: 59-63.

Reddy PS, MS John, PV Devi and SS Kumar, 2016. Nosocomial infections among patients admitted in general ICU: study from a tertiary-care hospital in South India. Int. J. Med. Sci. Pub. Health., 5: 21-27.

Roach DJ, JN Burton, C Lee, B Stackhouse, SM Butler-Wu, BT Cookson, 2015. A Year of Infection in the Intensive Care Unit: Prospective Whole Genome Sequencing of Bacterial Clinical Isolates Reveals Cryptic Transmissions and Novel Microbiota. PLoS Genet., 11: 258-267.

Saffar MJ, AA Enayti, IA Abdolla, MS Razai and H Saffar, 2008. Antibacterial susceptibility of uropathogens in three hospitals. Eastern Medit. Health J., 14: 450-477.

Sambrook J, EF Fritsch and T Maniatis, 1989. Analysis of genomic DNA by southern hybridization. In: Sambrook, J.; Fritsch, E.F. and Maniatis, T. (eds.) a laboratory manual, $2^{\text {nd }}$ (ed.) cold spring harbor laboratory press; pp.: 931-958.

Stefani S and A Agodi, 2000. Molecular epidemiology of antibiotic resistance. Int. J. Antimicrob. Agent., 13:143-153.

Steindl G., S Heuberger \& B Springer, 2012. Antimicrobial Effect of Copper on Multidrug-Resistant Bacteria. Wiener Tierarztliche Monatsschrift, 99: 38-43.

Todar K, 2008. Todar's Online Textbook of Bacteriology, Univ. of Wisconsin, Department of Bacteriology, PP.: 23-32.

Vos PD, GM Garrity, D Jones, NR Krieg, W Ludwig, FA Rainey, KH Schleifer and WB Whitman, 2009. Bergey's Manual of Systematic Bacteriology. 2nd ed. Vol. 3: The Firmicutes. Springer, New York.

Walker TS, 1998. Microbiology. $1^{\text {st }}$ ed., Saunders company, Philadelphia, USA.

Washington JA, 1985. Laboratory procedures in Clinical Microbiology, 2nd ed. Springer-Verlag, New York.

Yuksel S, B Ozturk, A Kavaz, ZB Ozcakar and B Acar, 2006. Antibiotic resistance of urinary tract pathogens and evaluation of empirical treatment in Turkish children with urinary tract infections. Int. J. Antimicrob. Agents., 5: 413-416.

Zavascki AP, CG Carvalhaes, RC Picao and AC Gales, 2010. Multidrug-resistant Pseudomonas aeruginosa and Acinetobacter baumannii: resistance mechanisms and implications for therapy. Ex. Rev. Anti-Infect. Therapy, 8: 71-93. 